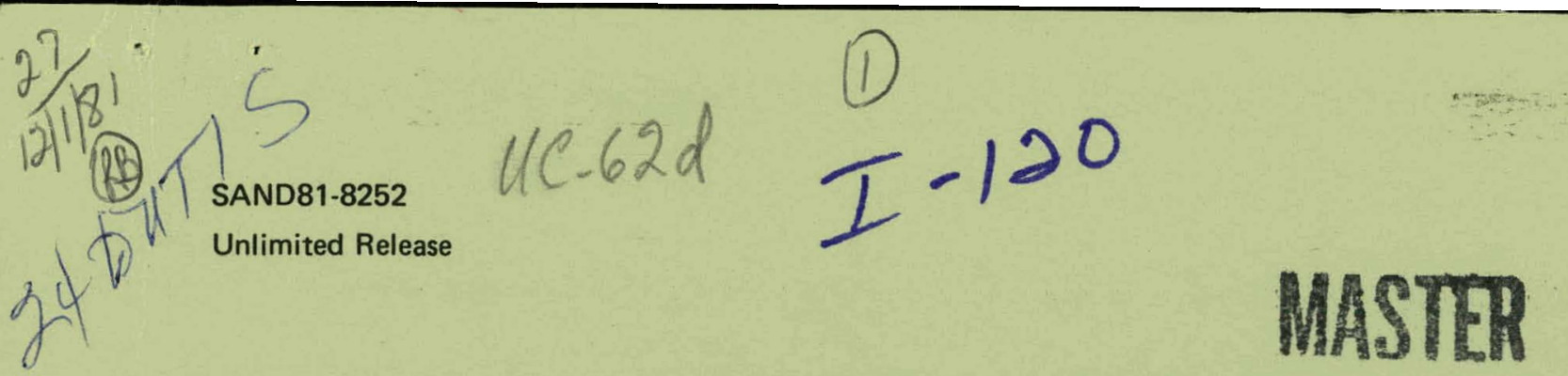

\title{
Characterization of the Corrosion Environment of the Desert Near Barstow, California
} Sos?

D. A. Hughes

Prepared by Sandia National Laboratories, Albuquerque, New Mexico 87185 and Livermore, California 94550 for the United States Department of Energy under Contract DE-AC04-76DP00789.

Printed September 1981

\section{Sandia Laboratories}




\section{DISCLAIMER}

This report was prepared as an account of work sponsored by an agency of the United States Government. Neither the United States Government nor any agency Thereof, nor any of their employees, makes any warranty, express or implied, or assumes any legal liability or responsibility for the accuracy, completeness, or usefulness of any information, apparatus, product, or process disclosed, or represents that its use would not infringe privately owned rights. Reference herein to any specific commercial product, process, or service by trade name, trademark, manufacturer, or otherwise does not necessarily constitute or imply its endorsement, recommendation, or favoring by the United States Government or any agency thereof. The views and opinions of authors expressed herein do not necessarily state or reflect those of the United States Government or any agency thereof. 


\section{DISCLAIMER}

Portions of this document may be illegible in electronic image products. Images are produced from the best available original document. 
Issued by Sandia National Laboratories, operated for the United States Department of Energy by Sandia Corporation.

\section{NOTICE}

This report was prepared as an account of work sponsored by the United States Government. Neither the United States nor the United States Department of Energy, nor any of their employees, makes any warranty, express or implied, or assumes any legal liability to responsibility for the accuracy, completeness or usefulness of any information, apparatus, product or process disclosed, or represents that its use would not infringe privately owned rights.

Printed in the United States of America Available from

National Technical Information Service

U. S. Department of Commerce

5285 Port Royal Road

Springfield, VA 22161

Price: Printed Copy $\$ 4.50$; Microfiche $\$ 3.00$ 


\section{PAGES 1 to 2 WERE INTENTIONALLY LEFT BLANK}


SAND81-8252

Unlimited Release

Printed September 1981

\section{CHARACTERIZATION OF THE CORROSION ENVIRONMENT \\ OF THE DESERT NEAR BARSTOW, CALIFORNIA}

Darcy A. Hughes

Materials Science Division - 8316

Sandia National Laboratories, Livermore

ABSTRACT

The corrosion characteristics of the desert atmosphere environment near Barstow, CA have been evaluated for the solar pilot plant receiver panel. Potential degradation mechanisms considered were hot corrosion from molten salts and stress corrosion cracking in aqueous environments. The possibility of degradation from these mechanisms depends on the chemical composition of airborne particulates, aerosols, and gases. These particulates and aerosols were collected near the pilot plant site and analyzed for water and acid soluble $\mathrm{Na}^{+}, \mathrm{Mg}^{++}, \mathrm{Li}^{+}, \mathrm{S}^{+}, \mathrm{SO}_{\overline{4}}$, and $\mathrm{Cl}^{-}$. Comparison and evaluation of the quantities of these ions present with those necessary for corrosion indicate that external corrosion of the receiver due to the desert atmosphere environment is unlikely. 
CONTENTS

Pàge

Introduction

Potential Corrosion Mechanisms

Experimental Procedures

Results and Discussion

Summary 25

Acknowledgements 25

References 26

Appendix A 28

Appendix B

29

Appendix C 30 


\section{LIST OF FIGURES}

Figure

Page

1 Water tower at Yermo Marine Corp Supply Center. Air samplers were mounted on tower catwalk.

2 Location of water tower with respect to the Solar Pilot Plant site.

3 Arrangement of air samplers around tower catwalk.

4 Wind frequency distribution for April, May, and June 1980, Apri1, May, and June 1969-1978, and annual average for 1955-1964.

5 Regions where soil samples were removed.

Sulfate concentrations for filter, tape, and soil samples.

7 Chloride concentrations for filter, tape, and soil samples.

8 Sodium ion concentration for filter, tape, and soil samples.

9 Magnesium ion concentration for filter, tape and soil samples.

in Manganese ion concenlraliun fupr flter, tape, and soit samples.

$11 \mathrm{pH}$ of the $0.04 \mathrm{~m}^{3}$ water extraction for the filter, tape, and soil samples.

\section{LIST OF TABLES}

1 Stress Corrosion Cracking of Alloy 800. 


\section{CHARACTERIZATION OF THE CORROSION ENVIRONMENT OF THE DESERT NEAR BARSTOW, CALIFORNIA}

\section{Introduction}

A major factor in site selection for solar thermal energy systems is the amount of insolation available per year. The large amount of insolation available in desert regions was a major consideration in siting a 10 MWe solar pilot plant ('Solar One') near Barstow, CA. Although there was no previous negative experience to cause concern, we had very little prior data with which to determine whether the desert atmosphere environment presents a corrosion problem for the solar receiver panel metal tubing. Because of the paucity of data, we felt it prudent to characterize and evaluate the desert environment near Barstow and analyse the results with respect to possible corrosion effects.

Receiver materials compatibility with the desert environment is influenced by both the operating temperature and materials of choice. The maximum design temperature 1,2 for the pilot plant receiver tubing, $650^{\circ} \mathrm{C}$, is achieved by focusing solar energy on the external surfaces of the panel tubing. The hot tubing then acts as a coupled boiler/heat exchanger, creating steam for electric power generation. Material for the receiver, alloy 800 , was chosen on the basis of successful experience with heat exchanger designs which employed the same working fluids, water/steam, inside the tubing. This experience, however, does not include the presence of desert air on the outside surface of the tubing. The typical external atmospheres for heat exchangers are neutral (non-oxidizing) flue gases which are less corrosive to some materials than ordinary air. Furthermore, desert atmospheres frequently contain dust which may contain "alkali" (a colloquialism for the salt residue of evaporating natural waters). Seasalt fallout, on the order of $0.337 \mathrm{~g} / \mathrm{m}^{2} /$ year, may also contribute to the salt content of the desert atmosphere 3 . A buildup of these natural salts, such as $\mathrm{NaCl}_{2} \mathrm{CaSO}_{4}, \mathrm{Na}_{2} \mathrm{SO}_{4}$ $\mathrm{K}_{2} \mathrm{SO}_{4}$, in the crevices of the tube panels could lead to hot corrosion from molten salts during the day and/or aqueous corrosion from repeated wetting by heavy nighttime dews.

The probability of corrosion from these mechanisms is dependent on the chemical composition of the airborne particulates and aerosols. Therefore, their collection and analysis is necessary in the determination of the desert environment's potential for damage to the receiver materials. This paper will describe the results of air sampling near Barstow and the subsequent characterization and evaluation of the desert environment's potential for damage to the receiver materials. Judgements concerning the potential for corrosion are presented and discussed. The baseline data generated on the environment is also applicable to heliostat compatibility; however, the scope of this report is restricted to receiver components. 
Potential Corrosion Mechanisms

Before defining the desert environment, potential corrosion mechanisms will be considered in more detail. Two mechanisms, stress corrosion cracking (SCC) and hot corrosion will be discussed for the receiver panel material, alloy 800 , which is an autentitic iron-nickel-chromium alloy. For the first mechanism, SCC, to occur in the receiver, three elements must all be present: stress, aggressive environment, and a susceptible material. The regions where these elements will most likely exist simultaneously are near the tube-to-header welds on the panel support structure. Stresses in these regions are at or below the yield strength of the alloy. They are comprised of residual stresses froin welding and forming operations, plus service loads. These areas also have horizontal surfaces where water from rain or dew, plus airborne particulates and aerosols can collect. Aqueous caustic or chloride solutions may thus be created in these areas. Alloy 800 exhibits SCC in both high concentration chloride and caustic solutions $4,5,6$. For any aqueous solution present, both temperature and concentration will vary as the receiver heats up diurnally and the water is evaporated. Boiling solutions $\left(100-160^{\circ} \mathrm{C}\right)$ could be present for several minutes each day during heatup. In this report the concentrations and exposure life for aqueous external environments of the receiver will be compared with laboratory tests to determine the probability for SCC. Examples of concentrations and exposure times for aqueous environments which have been shown to cause chloride and caustic cracking in alloy 800 are listed in Table 1.

The second potential degradation source, hot corrosion, is an accelerated oxidation and/or sulphidation process $7-11$. This process is promoted by molten salts and ions present on the surface of a metal at high temperatures, typically $600-1000^{\circ} \mathrm{C}^{12}$. Many hot corrosion mechanisms are possible depending on the temperature, metal composition, salt composition, and oxygen availability. For example, molten salts 13 such as $\mathrm{Na}_{2} \mathrm{SO}_{4}$ and $\mathrm{Na}_{2} \mathrm{O}$, can act as catalysts for oxygen-metal interaction. They can also react with oxide scales and metal substrate, causing alloy depletion and sulfidation. Chloride ions accelerate oxidation by cracking protective oxide scales and baring fresh metal for further oxidation. Molten salt sources include atmospheric $\mathrm{SO}_{3}, \mathrm{NaCl}, \mathrm{CaCl}_{2}$ and metal ions from the alloy. The amount of salt which is required to cause hot corrosion is estimated to be a replenished steady-state film of 0.01-0.001 $\mathrm{mg} / \mathrm{mm}{ }^{2}$ of surface10,11 and greater than $0.01 \mathrm{ppin} \mathrm{NaCl}$ in the atmosphere ${ }^{9}$.

Examples of eutectic sulfate and chloride salt compositions and melting points are presented in Table II 14 . Sulfate containing salts which are molten at receiver panel temperatures are likely to cause hot corrosion if present in sufficient quantities. The constituents of these salts are present in the desert environment; however, their quantities were unknown. The next two sections will describe the determination of these quantities and an evaluation of their corrosion significance at the levels present.

\section{Experimental Procedures}

To provide information on the desert atmosphere environment, two types of sampling techniques were used: high volume air sampling and flat plate collection. High volume air samplers, which operate similar to a vacuum cleaner, pull air through a paper filter at rates of approximately $35 \mathrm{~m}^{3} / \mathrm{hr}$. 
Table 1

Stress Corrosion Cracking of Alloy 800

\begin{tabular}{|c|c|c|c|}
\hline Environment* & Temperature $\left({ }^{\circ} \mathrm{C}\right)$ & Test Type & Life (hours) \\
\hline $10 \% \mathrm{NaOH}^{6}$ & 316 & $\begin{array}{l}\text { U-bend } \\
\sigma>.2 \% \text { Yield Strength }\end{array}$ & $\begin{array}{l}1000 \\
\text { (40\% Crack } \\
\text { Penetration) }\end{array}$ \\
\hline $875 \mathrm{ppm} \mathrm{Cl}^{-5}$ & 260 & $\begin{array}{l}\text { U-Bend } \\
\sigma>.2 \% \text { Yield Strength }\end{array}$ & 840 \\
\hline $100 \mathrm{ppm} \mathrm{Cl}^{-6}$ & 350 & $\begin{array}{l}\text { C-ring } \\
\sigma=2 \% \text { Yield Strength }\end{array}$ & 9000 \\
\hline $42 \% \mathrm{MgCl}_{2}{ }^{4,5}$ & 154 & $\begin{array}{l}\text { U-bend } \\
\sigma>.2 \% \text { Yield Strength }\end{array}$ & 68 \\
\hline
\end{tabular}

*Tests performed in undeaerated water for $\mathrm{Cl}^{-}$environinents and deaerated water for $\mathrm{OH}^{-}$. 
Table 2

Melting Points of Several Chloride and Sulfate Eutectic Salts 14

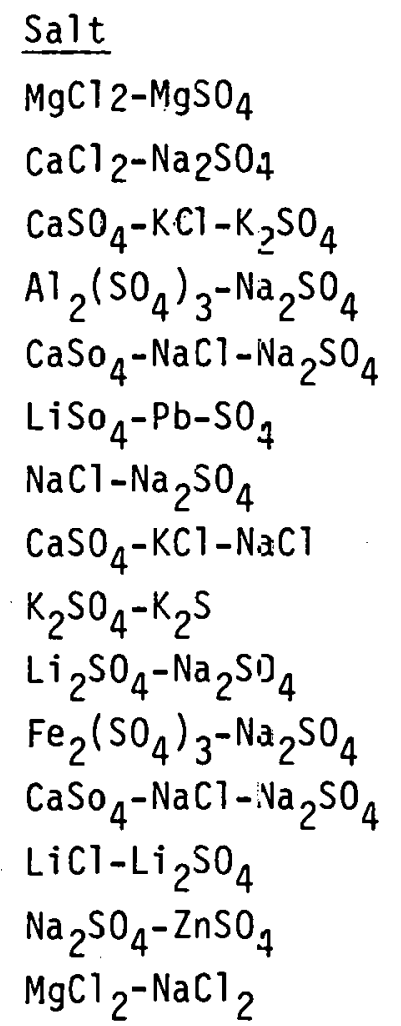

\begin{tabular}{lc} 
Eutectic Composition & Melting Point $\left({ }^{\circ} \mathrm{C}\right)$ \\
\hline $81-19$ & 657 \\
$91.5-8.5$ & 645 \\
$13.5-58.1-28.4$ & 644 \\
$17.6-82.4$ & 640 \\
$18.8-46.1-35.1$ & 633 \\
$78-22$ & 632 \\
$51.8-52.8$ & 628 \\
$10: 5-42.6-46.9$ & 605 \\
$43-57$ & 587 \\
$63-37$ & 584 \\
$17.5-82.5$ & 562 \\
$2.7-45.5-51.7$ & 485 \\
$63.5-36.5$ & 478 \\
$45-55$ & 472 \\
$40-60$ & 450
\end{tabular}


Flat plate collectors are passive samplers consisting of double sided sticky tape mounted on a flat vertical surface. Thus, flat plate collectors only gather particulates which impinge on their surface. These two techniques were chosen to complement each other; the high volume air samplers collect particulates and aerosols from a large volume of air and thereby yield a more sensitive air sample, while the flat plate collectors yield a more accurate representation of the quantity of particulates which might accumulate on the receiver panel. Prior to sampling, the air flow rate for the high volume air samplers was calibrated and the surface area of the sticky tape was noted (values in Appendix A). This calibration was necessary for subsequent normalization of particulate quantities to volume or area sampled.

Four samplers of each type were mounted at the top of a 23 meter tall water tower (Figure 1) at the Marine Corp Supply Center (Yermo area) two miles northeast of Daggett. The location of this tower with respect to the pilot plant is shown in Figure 2. It would have been preferable to mount the samplers at an elevation comparable to the elevation of the pilot plant central receiver $(85 \mathrm{~m})$. Ilowever an existing structure of that height was not available for mounting the samplers. The water tower was chosen since it was the tallest structure available; nevertheless it is believed that the particulates sampled at this elevation are reasonably representative of the external environment of the receiver.

When positioning the samplers on the tower (Figure 3), care was taken to place the flat plate collectors into the prevailing wind to maximize particulate collection. The prevailing wind direction was determined by 10 years of climatic data and was consistent with the actual wind patterns during the sampling period, April 8 through May 9, 1980 (Figure 4) 16 . During this period the samplers provided continuous collection of particulates; filters and tapes were changed weekly by marine base personnel. Flat plate collection was terminated the week of April 25 because a wind storm blew the small lightweight plate collectors off the tower.

In addition to air samples, soil samples were taken from regions near the tower as located in Figure 5. The soil samples were collected for comparison and possible correlation of the dust particulates in the air and the soil.

At the end of the sampling period all collected samples were analyzed using wet chemistry by Trace Analysis Laboratories in Hayward, CA. This analysis determined the $\mathrm{pH}$ and amounts of the following water and acid extracted ions: $\mathrm{Na}^{+}, \mathrm{Mg}^{++}, \mathrm{Mn}^{++}, \mathrm{Li}^{+}, \mathrm{Cl}_{-}^{-}, \mathrm{SO}_{4}^{\overline{4}}$, and $\mathrm{S}^{=}$. These ions are considered to be the most important from the standpoint of corrosion. (The analytical procedures are presented in Appendix B). X-ray diffraction was also performed on one filter sample to determine the type of particulates present.

\section{Results and Discussion}

The results of chemical analyses of the filter, tape and soil samples are presented in Figures 6 through 11. Each figure is a series of three bar-graphs showing ion concentration normalized to sample weight (sample weights are given in Appendix C) versus location and date for filter and 


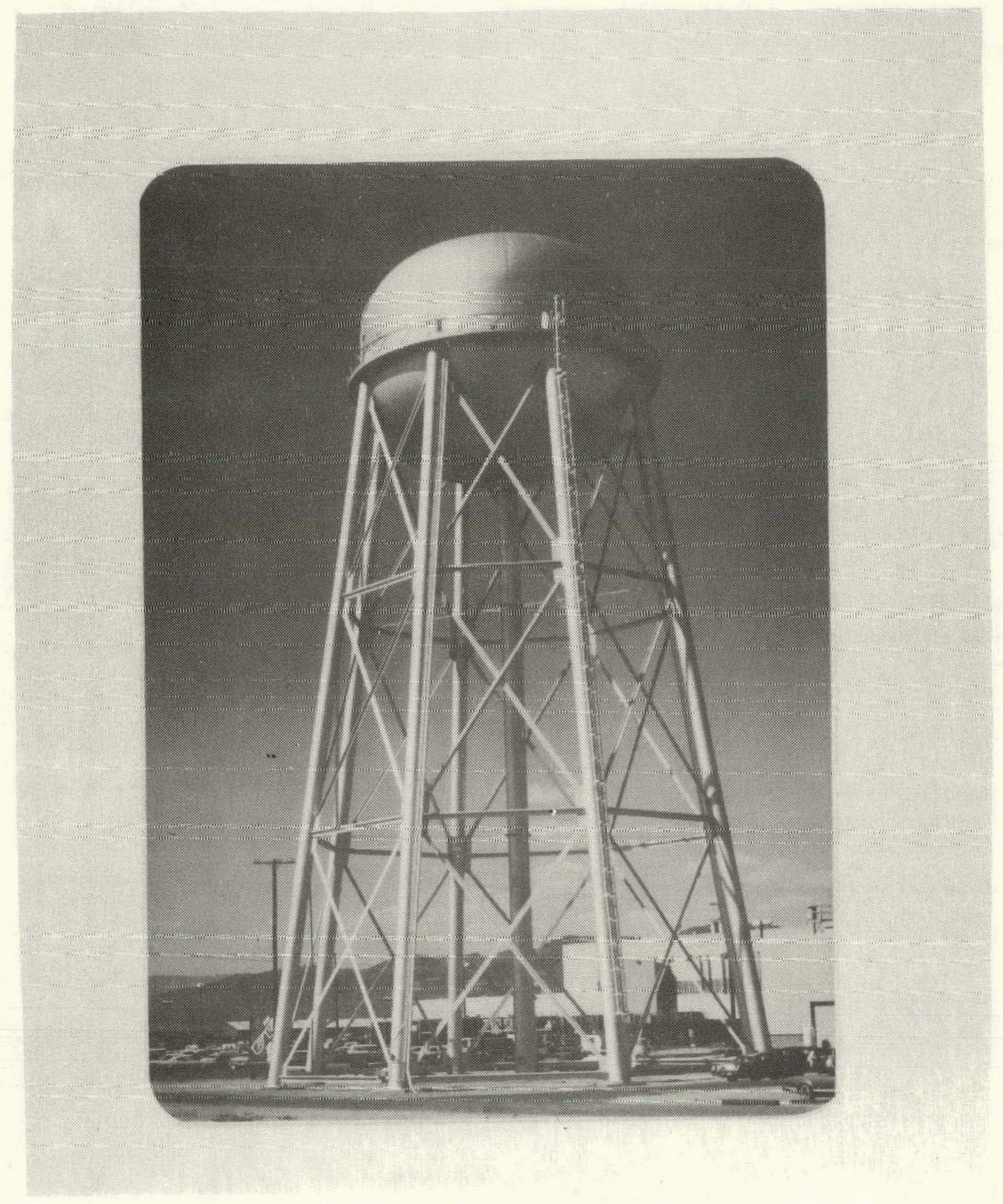

Figure 1. Water Tower at Yermo Marine Corp Supply Center, Air Samplers were Mounted on Tower Catwalk. 


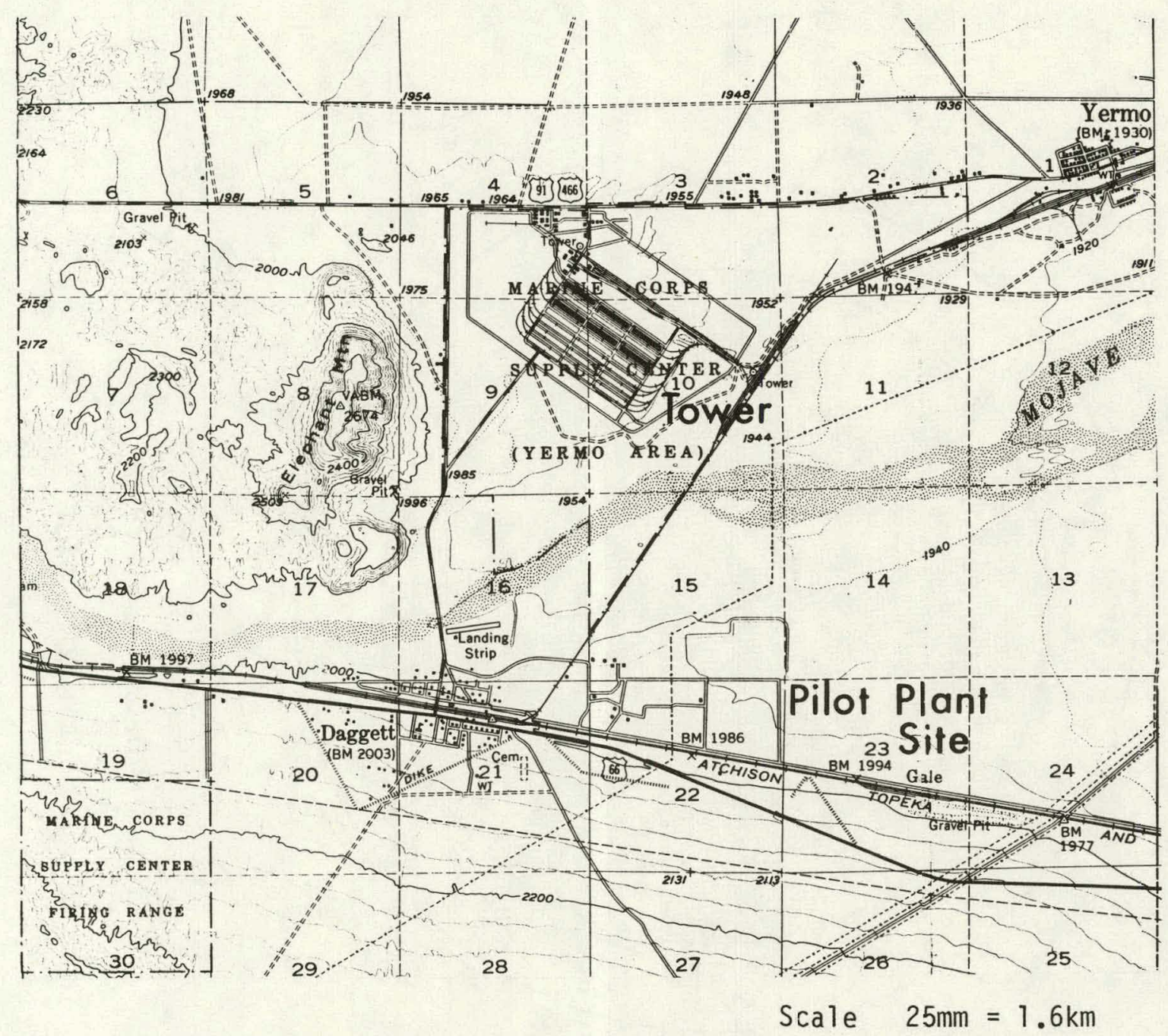

Figure 2. Location of Water Tower with Respect to the Solar Power Plant Site ${ }^{15}$. 


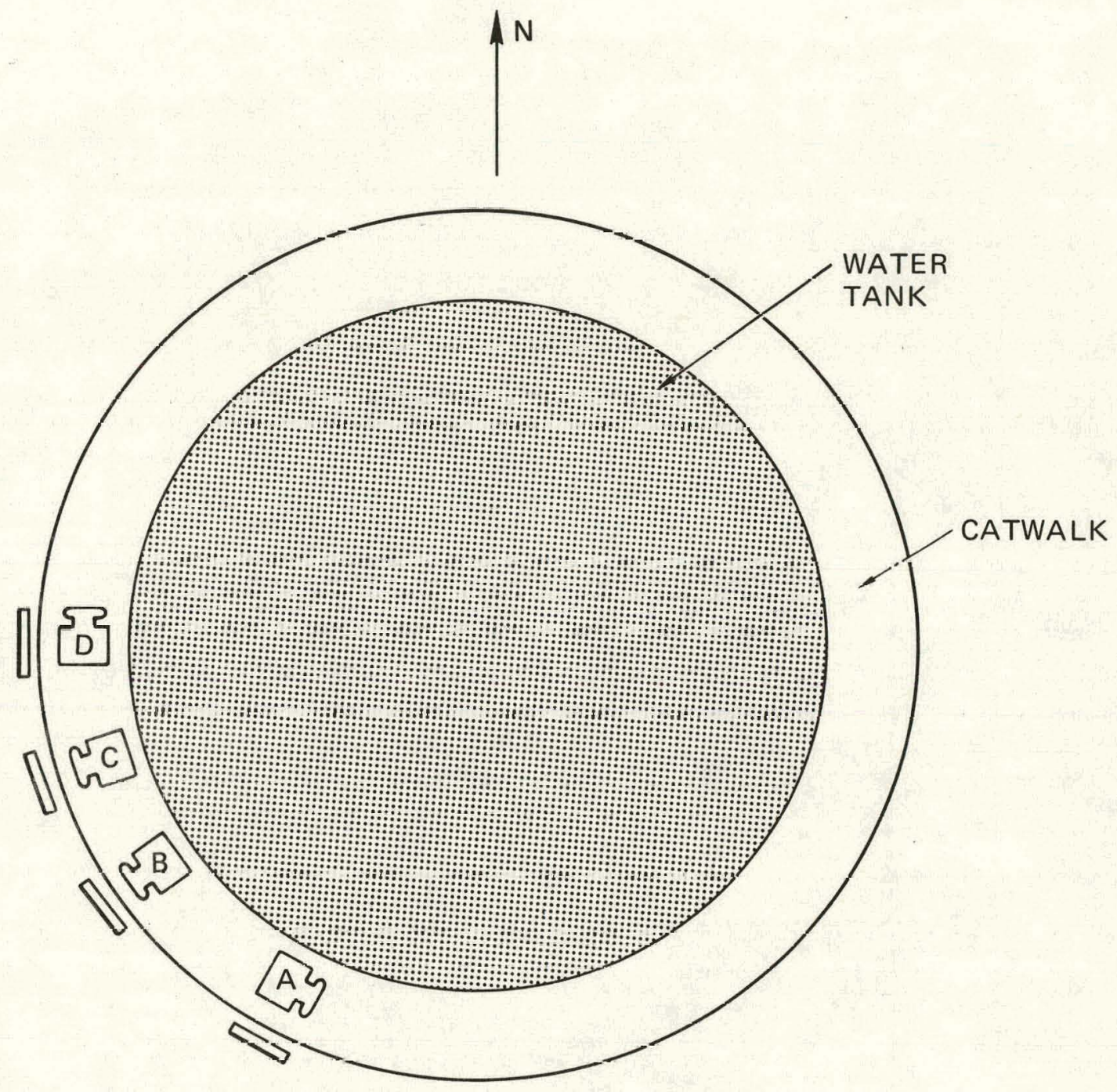

$\checkmark$ HIGH VOLUME AIR SAMPLER

$\Longrightarrow$ FLAT PLATE COLLECTOR

Pigure 3. Arrangement of air samplers around tower catwalk。 
Maximum Wind Direction Frequency Distribution

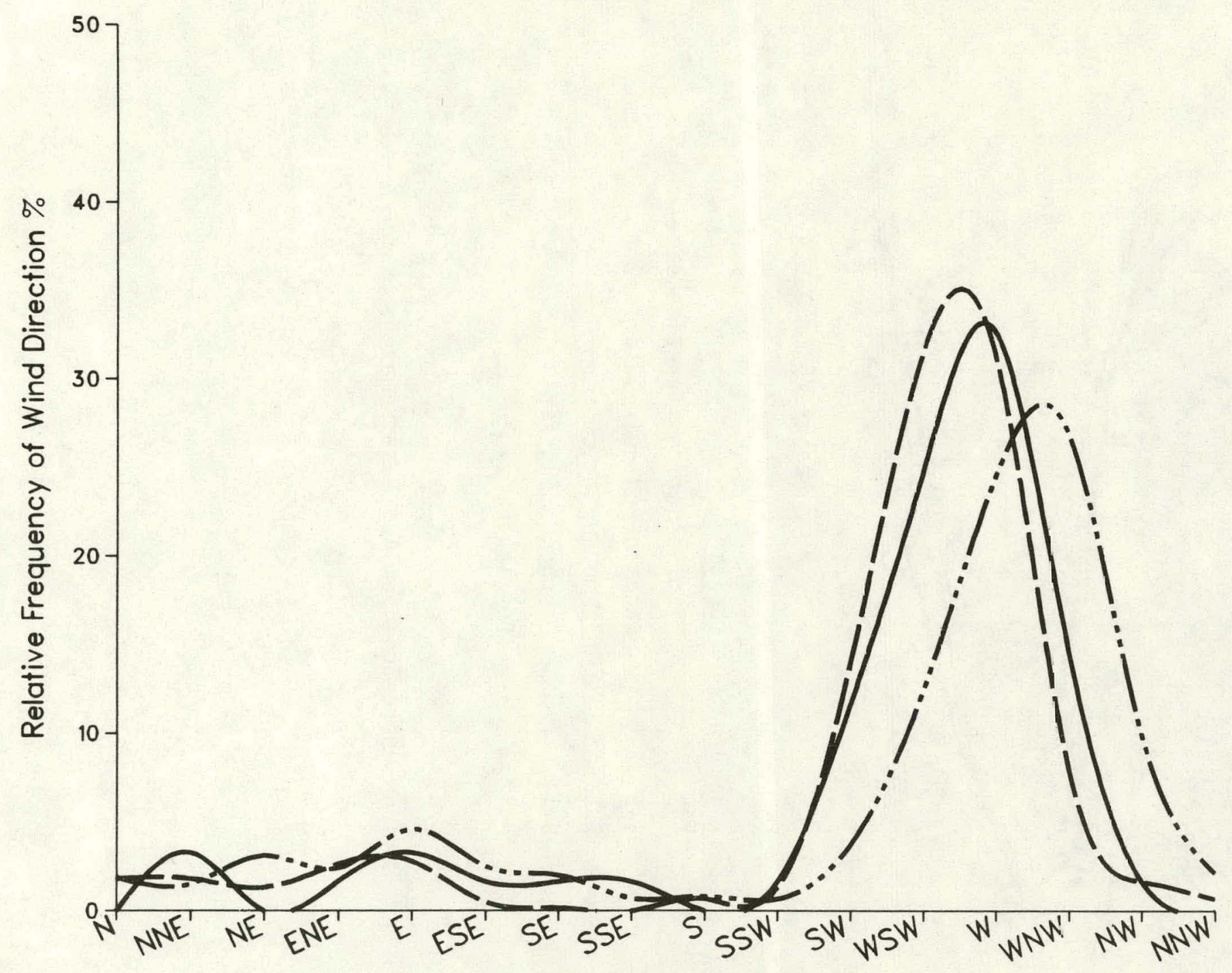
annual average for 1955-1964. 


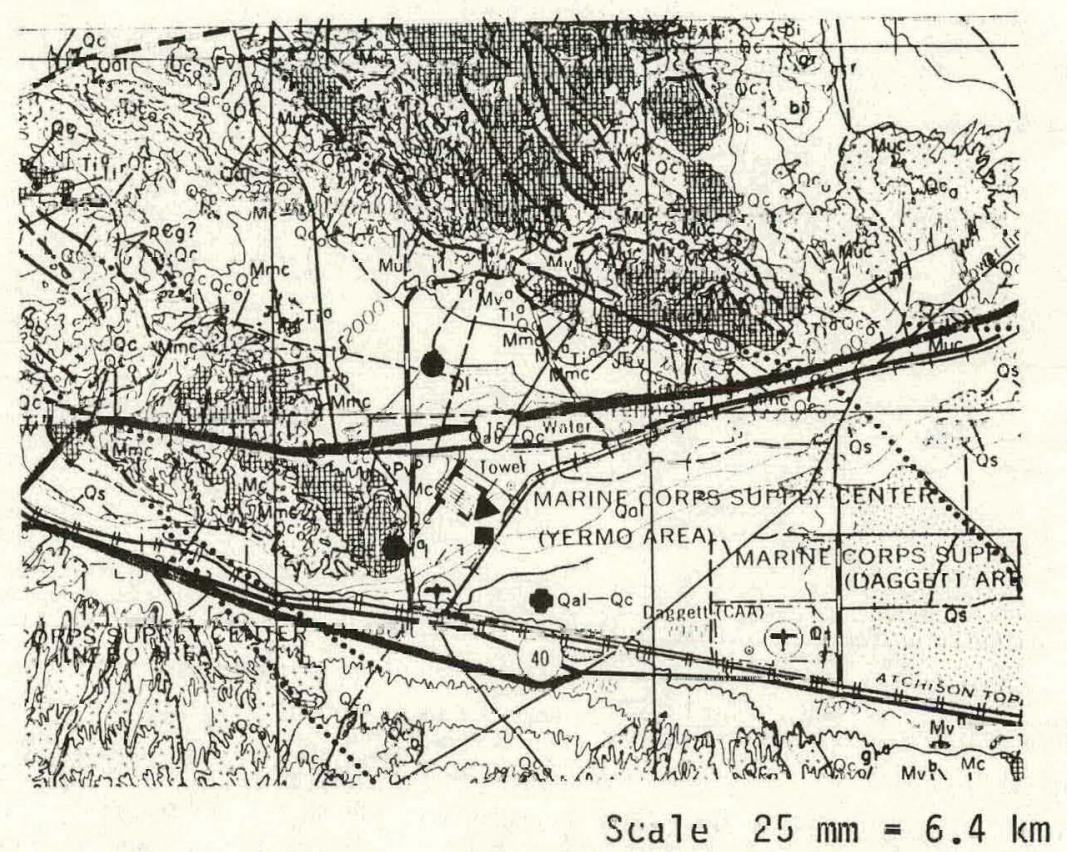

\begin{tabular}{ccl} 
Symbol Soil Sample & & Location \\
\cline { 1 - 2 } & $1-3$ & Pilot plant construction site \\
& $4-6$ & Beneath and near water tower \\
- & $7-8$ & Yermo supply center \\
& $9-11$ & Elephant mountain \\
& 12 & Dry lakebed
\end{tabular}

Figure 5. Regions Where Soil Samples Were Removed 17 . 
tape samples or location for soil samples. Water and acid extraction results are placed side by side on each graph. On average the ion concentrations were very small for all samples; sulfate (Figure 6) was the most prevalent ion. Chloride (Figure 7) was not found in any sample by water extraction. However, a few soil and tape samples contained acid extractable chlorides. Since the acid extractable chlorides are tied up in water insoluble minerals they will not be available for aqueous corrosion. of the metal ions, sodium (Figure 8) was the most common with lesser amounts of magnesium (Figure 9) and manganese (Figure 10) present.

Concentrations of $\mathrm{s}$ and $\mathrm{Li}^{+}$are not shown in the figures because they were below the detection limits of .024 and $.002 \mathrm{mg}$ per sample respectively. One soil sample from the dry lakebed, location 12 in Figure 5 , is an exception and had a $\mathrm{Li}^{+}$concentration of $.02 \mathrm{moles} / \mathrm{Kg}$ of sample. Analyses for $\mathrm{Ca}^{++}$and $\mathrm{K}^{+}$concentrations performed on one filter sample (4-25-80-A) yield 0.349 moles $/ \mathrm{kg}$ of $\mathrm{Ca}^{++}$and 0.054 moles $/ \mathrm{kg}$ of $\mathrm{K}^{+}$. Ca ${ }^{++}$is present in a quantity similar to $\mathrm{Na}^{+}$concentrations, while $\mathrm{K}^{+}$is approximately a factor of 10 less.

In general, the filter samples showed the largest concentrations of soluble ions, followed by the tape and then the soil samples. Factors which contribute to this difference are particle size and type of sample collected. The relatively large particulates in the soil samples yield less soluble ions per unit weight; most of the soil samples contained a large proportion of inert minerals. Only the soil sample from the dry lakebed contained significant soluble salts. Filters from the high volume air samplers contain very fine particulates and also tend to pick up aerosols which would be water soluble, thus yielding higher concentrations. (Aerosals and fine particulates are easily trapped in the filter as air is drawn through and are less likely to deposit on the tape). The filters also picked up significantly more $\mathrm{S} 0 \overline{\overline{4}}$ (Figure 6) than the tapes. The $S O \overline{4}$ concentration is attributed to atmospheric $\mathrm{SO}_{2}$ and $\mathrm{SO}_{3}$ concentrations from sources of smog such as vehicle exhaust and oiT fired power plants in the area ( $i . e$. Southern California Edison Cool Water Plant and smaller plants on the Marine Base). For $\mathrm{SO}_{4}$ to form, $\mathrm{SO}_{2}$ or $\mathrm{SO}_{3}$ gas must react with moisture forming $\mathrm{H}_{2} \mathrm{SO}_{4}$. The hydrophillic paper filters, unlike the tapes, provide an ideal location for this reaction to occur. Comparing the tape and filter samples with the soil samples, it appears that the soil is not the primary source of ions; air pollutants may be a more important source.

Two filter samples were also analyzed using X-ray diffraction to determine what mineral forms were present in the particulates. The results indicate the presence of $\mathrm{SiO}_{2}$ (alpha quartz), $\mathrm{KAlSi} \mathrm{O}_{8}$ (orthoclase), $\mathrm{KAl}_{2} \mathrm{Si}_{3} \mathrm{AlO}_{10}(\mathrm{OH})_{2}$ (muscovite), and $\mathrm{Na}_{2} \mathrm{Mg}_{5} \mathrm{Si}_{12} \mathrm{O}_{30}$ (sodium magnesium silicate) .

Relating the quantities of ions found to the probability of corrosion is very difficult because of the many unknowns which cannot be positively determined. Foremost among these are a mechanism(s) for the localized accumulation of contaminants, and unforeseen extraordinary salt loadings. With these caveats in mind, the following discussions will present one way of analyzing the data for the probability of corrosion. The aim of the discussion is to give the reader a feel for the relative quantities of salts found. The necessary assumptions for this analysis are listed below.

1. Samples collected over a one month period are assumed to be typical 
CONCENTRATION OF $\mathrm{SO}_{4}=$ FOR FILTER SAMPLES

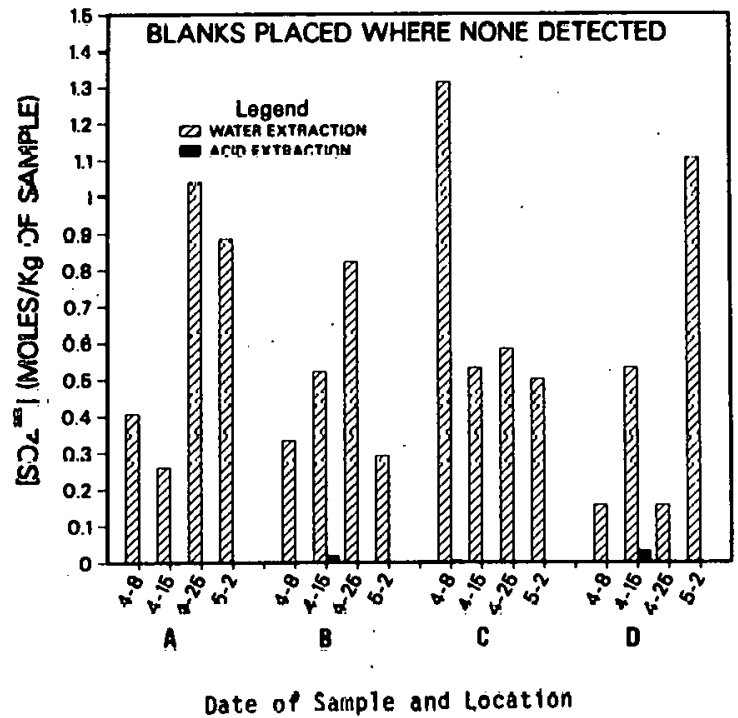

CONCENTRATION $\mathrm{SO}_{4}=$ FOR TAPE SAMPLES

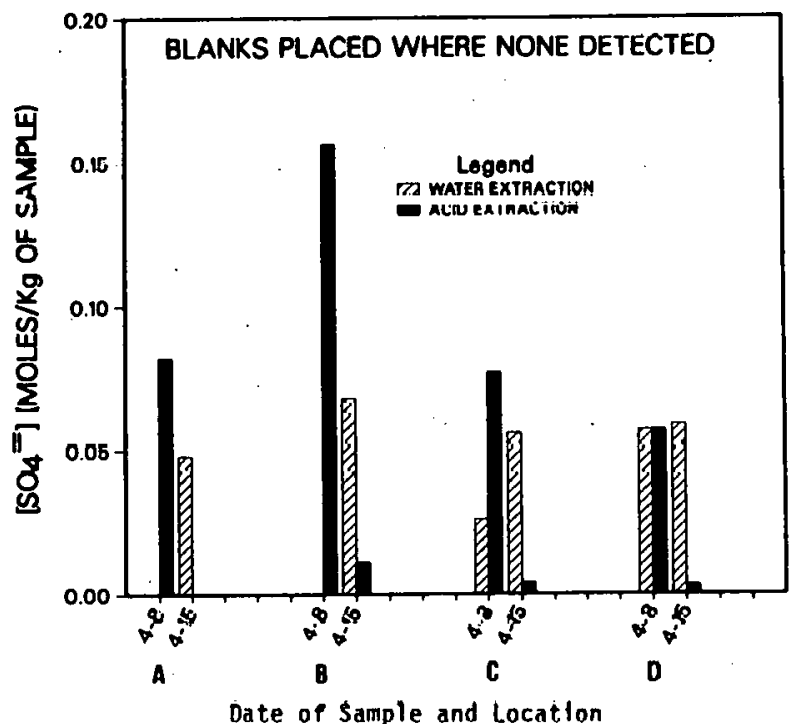

CONCENTRATION OF $\mathrm{SO}_{4}=$ FOR SOIL SAMPLES

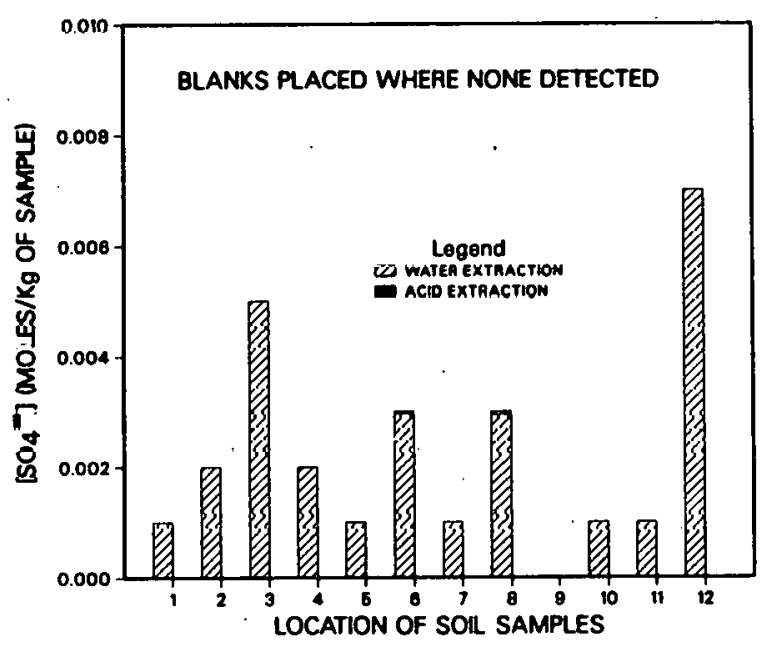

Figure 6. Sulfate concentrations for filter, tape, and soil samples. 

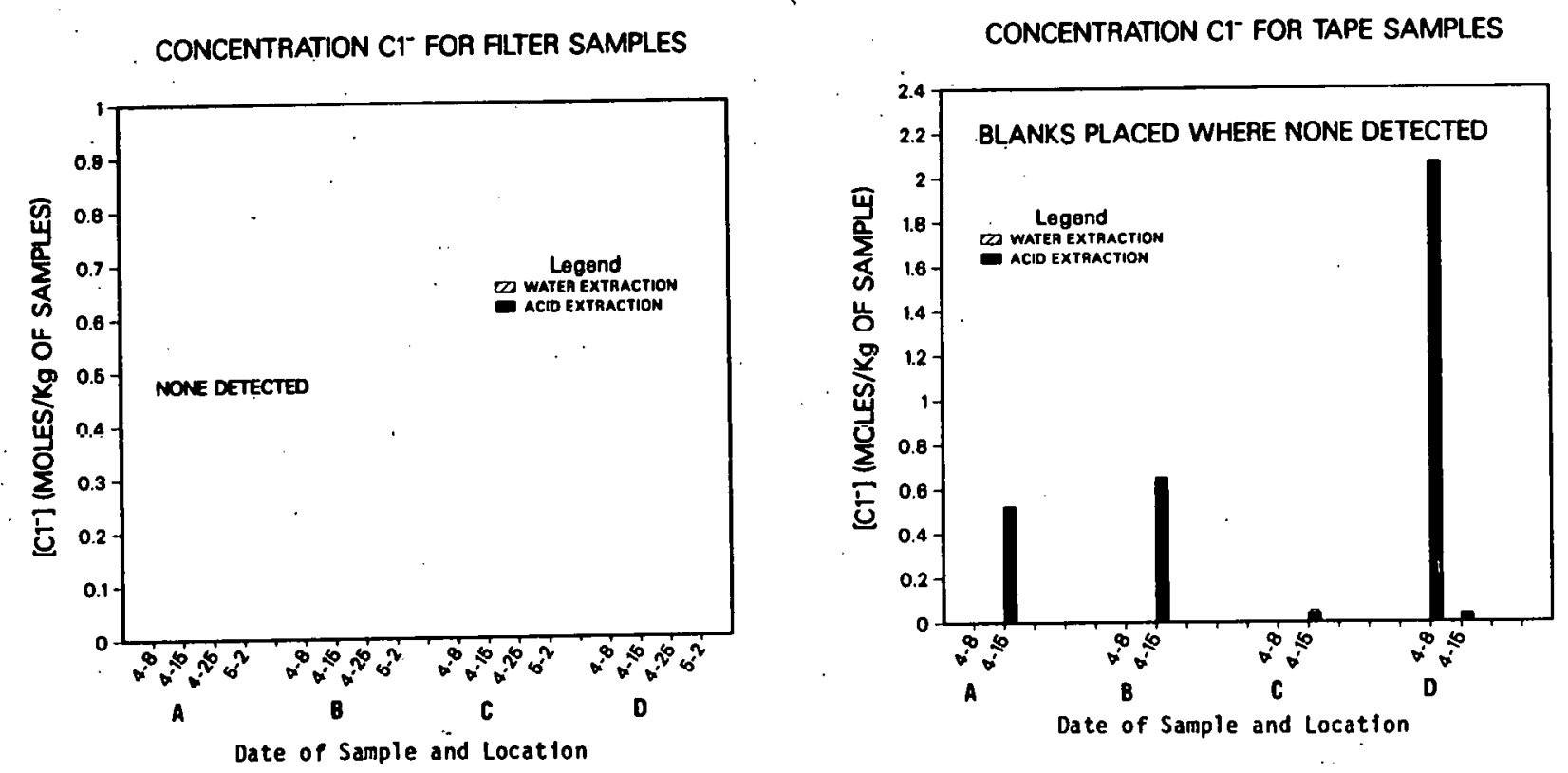

Date of Sample and Location

CONCENTRATION C1- FOR SOIL SAMPLES

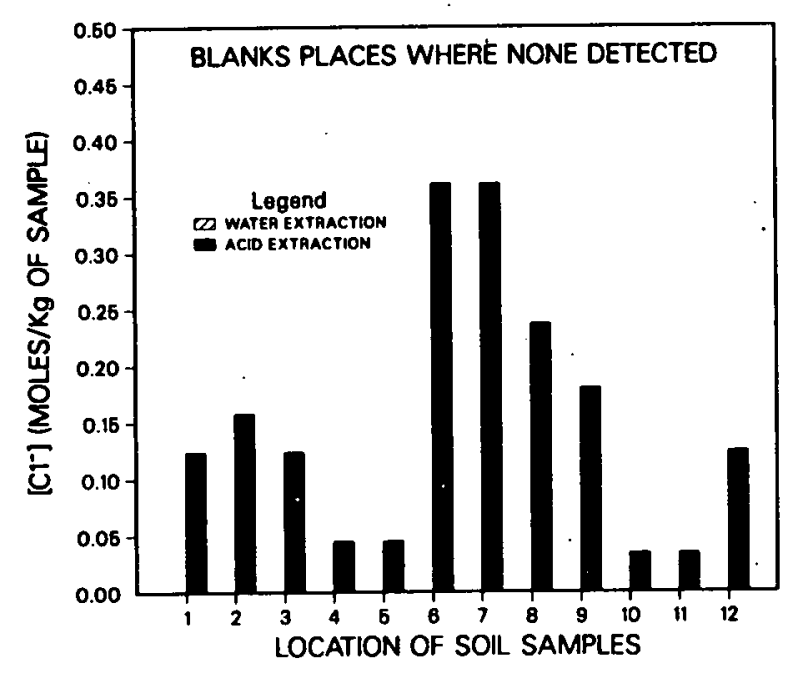

Figure 7. Chloride concentrations for filter, tape, and soil samples. 
CONCENTRATION OF Na ${ }^{+}$FOR FILTER SAMPLES

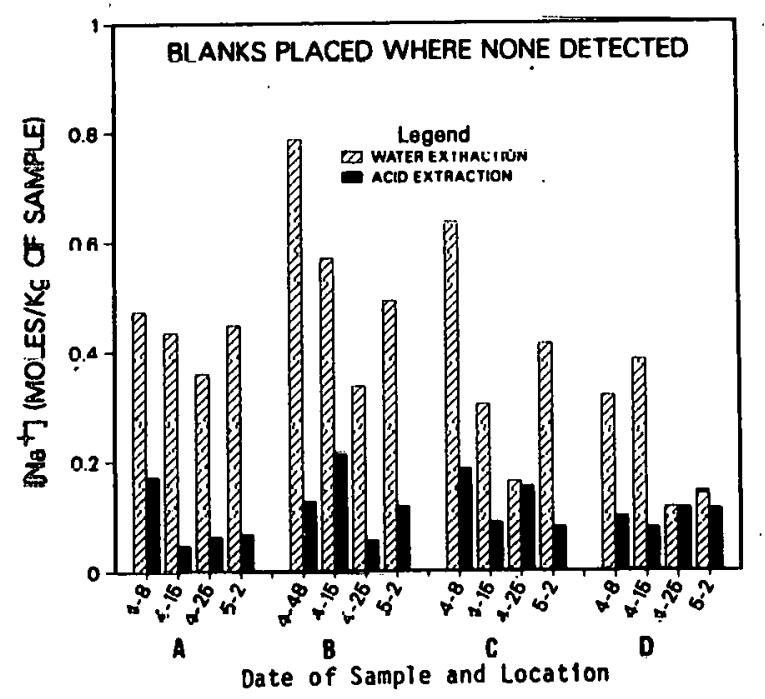

CONCENTRATION OF $\mathrm{Na}^{+}$FOR TAPE SAMPLES

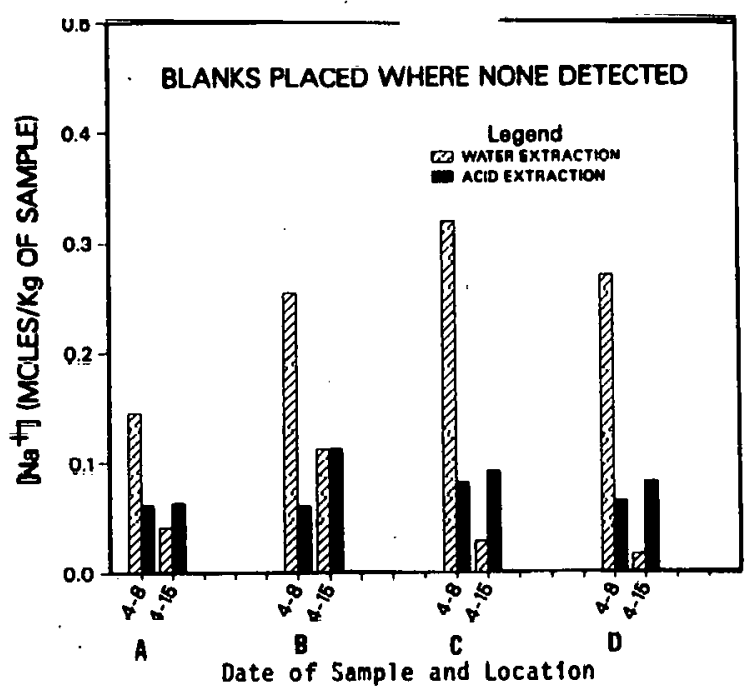

CONCENTRATION Na ${ }^{+}$FOR SOIL SAMPLES

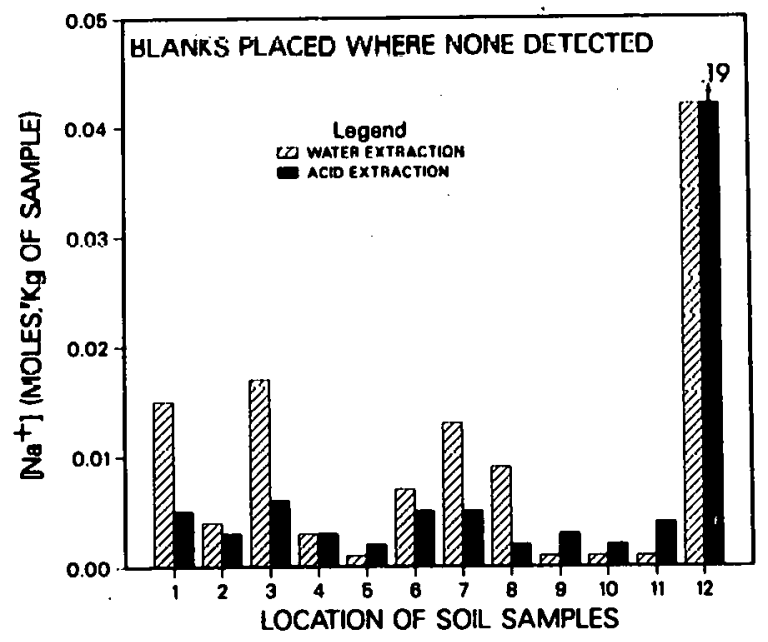

Figure 8. Sodium ion concentration for filter, tape, and soil samples. 
CONCENTRATION OF $\mathrm{Mg}^{++}$FOR FLTER SAMPLES

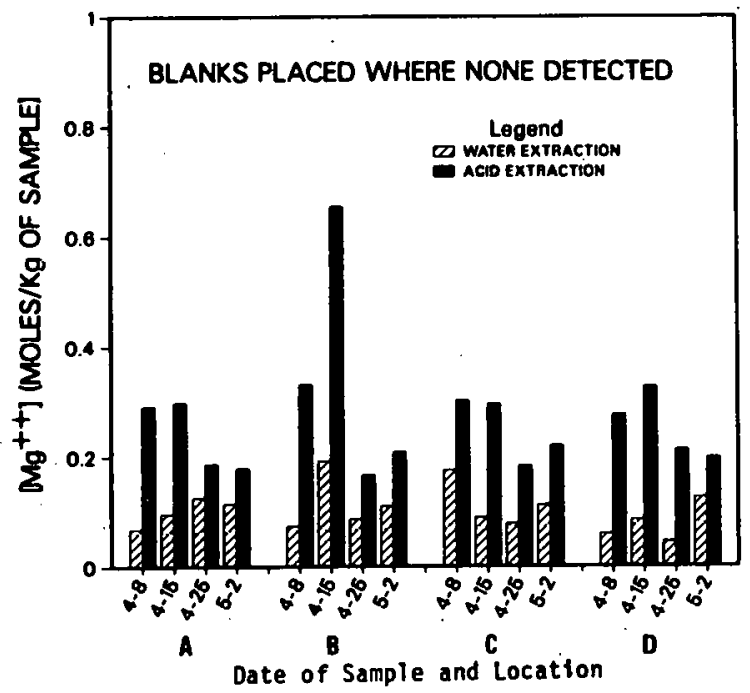

CONCENTRATION OF $\mathrm{Mg}^{++}$FOR TAPE SAMPLES

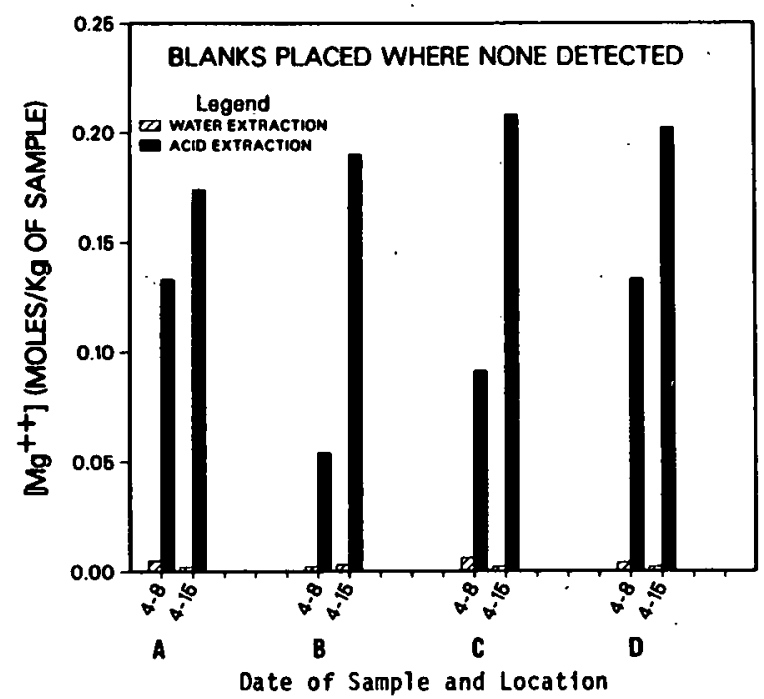

. CONCENTRATION OF Mg ${ }^{++}$FOR SOIL SAMPLES

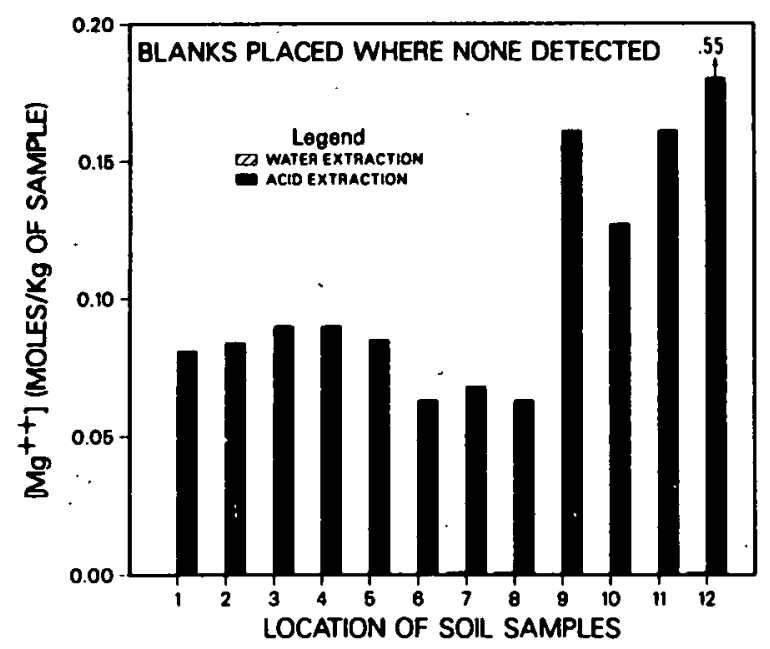

Figure 9. Magnesium ion concentration for filter, tape and soil samples. 
CÜNCENTRATION OF $\mathrm{Mn}^{++}$FOR FLTER SAMPLES

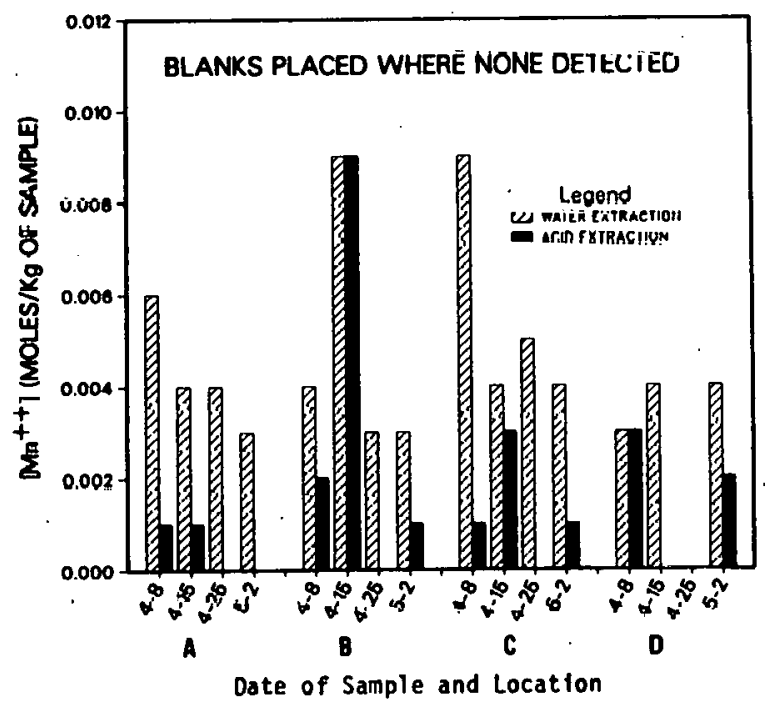

CONCENTRATION OF $\mathrm{Mn}^{++}$FOR TAPE SAMPLES

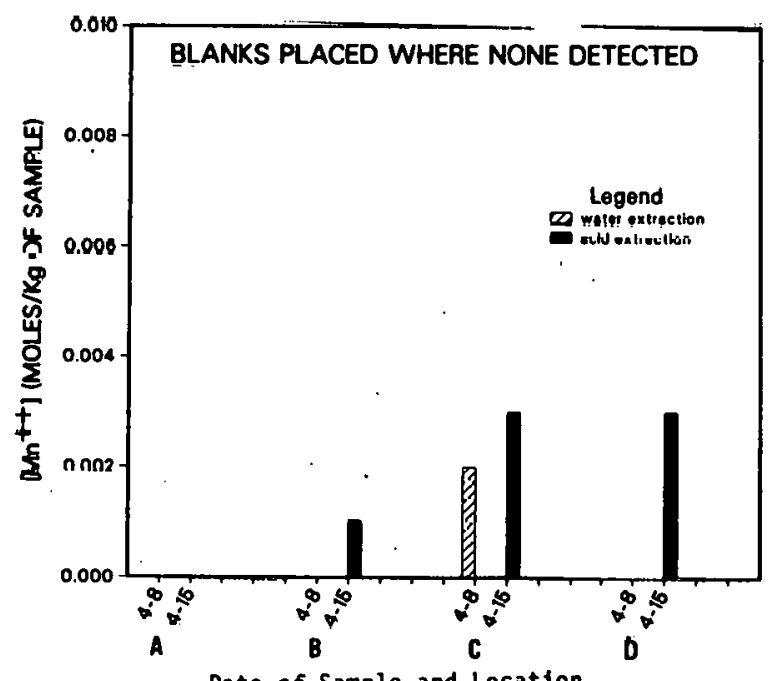

Date of Sample and Location

CONCENTRATION OF Min ${ }^{++}$FOR SOIL SAMPLES

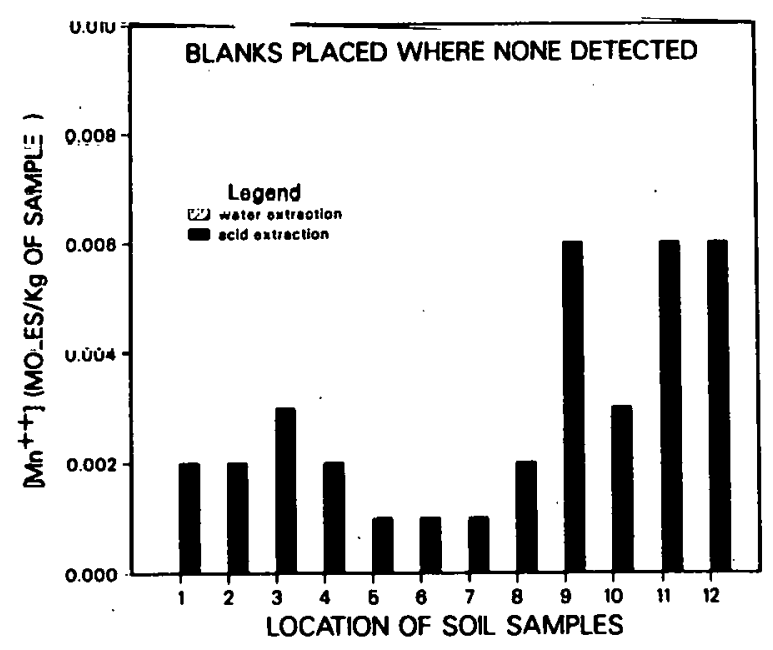

Figure 10. Manganese ion concentration for filter, tape, and soil samples. 

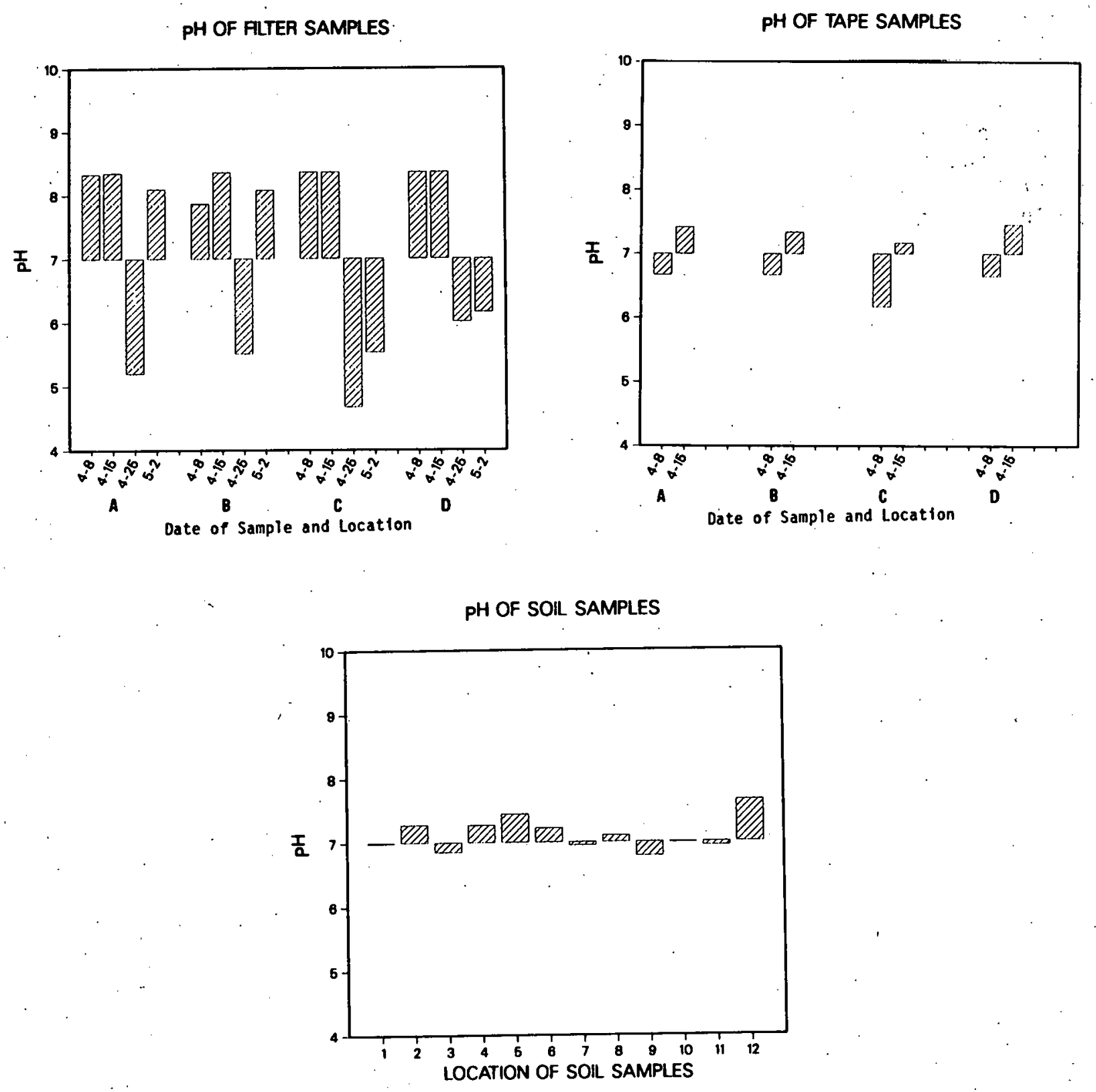

Figure 11. $\mathrm{pH}$ of the $0.04 \mathrm{~m}^{3}$ water extraction for the filter, tape, and soil sample. 
and representative of the whole year and of the average year. Wind directions and speeds are key factors in determining the amount and kind of particulates in the air. Comparisons of the distributions of maximum wind direction for the sample period, ten years of wind data on that period of the year and the whole year are shown in Figure 4; all follow similar trends.

2. Particulates are assumed to accumulate uniformly during the year and then be washed away each year during the short rainy season. Other methods of ion concentration buildup will be considered later when appropriate.

3. The uniform accumulation is assumed to be equivalent to the concentration gathered on the sample, over the week with maximum concentration of ion, multiplied by the number of weeks per year. The combination of both these assumptions is conservative because all of the particulates which impinge on the sticky tape adhere. Particulates are not subject to the removal actions of wind and rain as they would be on the receiver.

4. The concentration of anions, $\mathrm{SO}_{4} \overline{4}$ and $\mathrm{Cl}^{-}$are assumed to be limiting factors in molten salt formation. Figures 8 through 10 show that there are adequate metal ions to form one or more of the eutectic salts listed in Table 2. Ion combination mechanisms and any difficulties in salt formation will not be considered limiting (very conservative assumption).

5. Water soluble chlorides were not detected; therefore the quantity of $\mathrm{Cl}^{-}$will be based on the detection limit of $0.4 \mathrm{mg}$ per sample. This is conservative because a second anlalys is of one filter did not find $\mathrm{Cl}^{\text {"' }}$ with a detection limit of $0.04 \mathrm{mg}$ per sample.

6. For filter samples and determination of the equivalent concentration of $\mathrm{SO}_{3}$ in air, we assume that all $\mathrm{SO}_{3}$ which passed through the filters is converted to $\mathrm{SO}_{4}$.

7. The calculated volume of air (Appendix A) passing through the filters is based on the initial calibration of flow rate. A factor of $1 / 2$ is included to account for a decrease in flow rate as the filter becomes loaded with particulates.

Based on these assumptjons the amount of chloride which would accumulate on a panel surface is $8 \times 10^{-4} \mathrm{mg} / \mathrm{mm}^{2} /$ year. (i.e. $0.4 \mathrm{mg} / 25800 \mathrm{~mm}^{2} \times 52$ weeks per year). To determine whether this amount of chioride would cause SCC, the amount of $\mathrm{Cl}^{-}$is translated into: 1) a depth of aqueous solution for the concentrations given in Table 2, and 2) an average daily duration of this solution on the receiver during heatup. The approximate duration of the solution is then compared with the 1 ifetimes or necessary exposure times from Table 2. Given the $8 \times 10^{-4} \mathrm{mg} / \mathrm{mm}^{2} /$ year $\mathrm{Cl}-$, one would need a $0.55 \mu \mathrm{m}$ depth of water to achieve the equivalent of a $42 \% \mathrm{MgCl}_{2}$ solution. (Note $42 \% \mathrm{MgCl}_{2}$ is a saturated solution). Water of this depth would last less than one second each day during heatup, far short of the 1.1 minutes (i.e. $68 \mathrm{hrs} . \mathrm{x} 60 \mathrm{~min} / \mathrm{hr} / 3650$ days in 10 years) exposure per day needed to accumulate 68 hours ( 1 ife in $42 \% \mathrm{MgCl}_{2}$ over a ten year period). The $875 \mathrm{ppm} \mathrm{Cl}^{-}$ solution with an 840 hour iife requires a depth of $.9 \mathrm{~mm}$ of water for 15 minutes a day for ten years to cause failure; 15 minutes is a much longer exposure than possible for the receiver. Consideration of the $100 \mathrm{ppm} \mathrm{Cl}$ - solution yields 
similar results; exposure to an $8 \mathrm{~mm}$ depth of water for 2-1/2 hours per day during heat-up would not occur on the external surfaces of the receiver. A1though these three examples do not cover every possibility, they are adequate since they span the range of $\mathrm{Cl}^{-}$concentrations.

High concentration aqueous caustic solutions would also be improbable, as shown by the nearly neutral $\mathrm{pH}$ of the samples in Figure 12. Thus, since only minute amounts of $\mathrm{Cl}^{-}$and $\mathrm{OH}^{-}$are present, it is unlikely that external aqucous corrosion or SCC would occur on the receiver pallel.

The amount of eutectic salt film possible for hot corrosion is estimated by considering the equivalent amounts of $\mathrm{SO}_{4}^{\overline{4}}$ and $\mathrm{Cl}{ }^{-}$. This yields $0.004 \mathrm{mg} / \mathrm{mm}^{2} /$ year accumulation of $\mathrm{Na}_{2} \mathrm{SO}_{4}-\mathrm{CaSO}_{4}$ and $0.0013 \mathrm{mg} / \mathrm{mm}^{2} /$ year $\mathrm{NaCl}$. These small values are a factor of ten less than that established in the previous section on hot corrosion in gas turbines. For the receiver, hot corrosion would most likely occur in the top $4 \mathrm{~m}$ section of the panel where the temperatures are maximum (the temperature of the panel jumps abrubtly from $300^{\circ} \mathrm{C}$ to $460^{\circ} \mathrm{C}$ where departure from nucleate boiling occurs, approximately $4 \mathrm{~m}$ below the top). If all the salt from the top $4 \mathrm{~m}$ of the panel were to collect in a narrow band, this would yield only $14 \mathrm{mg} / \mathrm{mm}$ circumference of salt around the panel. Both the uniform film accumulation and vertical accumulation model generate insignificant quantities of salt for hot corrosion. Also the quantities of $\mathrm{SO}_{3}$ and $\mathrm{Cl}^{-}$in the air which would contribute to the films are very small: $0.61 \mathrm{ppb}$ $\mathrm{SO}_{3}$ and $0.088 \mathrm{ppb} \mathrm{Cl}^{-}$air based on the maximum from the filter samples. Thus, from these considerations, external hot corrosion is also very unlikely.

\section{Summary}

Airborne particulates and aerosals were sampled in the desert near the solar pilot plant site. The collected: samples were analyzed for the concentrations of water and acid soluble $\mathrm{Na}^{+}, \mathrm{Mg}^{++}, \mathrm{Mn}^{++}, \mathrm{Li}^{+}, \mathrm{Cl}-, \mathrm{SO}_{4}^{=}$and $\mathrm{S}^{=}$. Screening for these ions was done to determine if the desert environment would present a corrosion problem for the solar receiver panel. The concentrations of ions present in the samples were compared to data on hot corrosion and.SCC. Based on these comparisons and the small amounts of these ions present, it is unlikely that either hot corrosion or SCC caused by the external desert environment will occur on the receiver panel.

\section{Acknowledgement}

I am grateful to $T$. Devlin and $L$. Brewer for discussions on air sampling techniques, C. L. Mason and coworkers at the Marine-Corp. Supply Center, Yermo area for their cooperation and assistance in monitoring the samplers, $H$. C. Feemster for chemical analysis, C. A. Scott for compilation of climatic data, D. R. Boehme for X-ray analysis and to C. F. Casey for typing the manuscript. I...acknowledge the chemical analys is of $S$. Furman. 


\section{References}

1. Wolf, S., Chen, K., Yant, T. M. and Simpson, J. L., Performance Analysis for the MDAC Rocketdyne Pilot and Commercial Plant Solar Receivers, SAND78-8183, Sandia National Laboratories, September 1978.

2. Payne, H. M., MDAC/Rocketdyne Solar Receiver Design Review, SAND78-8188, Sandia National lahnratories, November 7978.

3. Bricrly, W. B., "Atmosphere Sea-Salts Design Criteria Areas", J. of Environmental Sciences; Vol. 8, No. 5, October 1965, p. 15.

4. Scdriks, A. J., "Stress Corrosion Cracking of Stainless Steels and Nickel Alloys", J. of the Institute of Metals, Vol. 101, 1973, p. $22 \mathrm{~b}$.

5. Sedriks, A. J., "Evaluation of Alternate Alloys for PWR Steam Generators First Semi-annual Report (August 1979-January 1980)", prepared for the Electric Power Research Institute under contract RP-1450-1.

6. Blanchet, J. and Coriou, H., "Review of the Corrosion Resistance Properties of Alloy 800 in High-Temperature Steam", Alloy 800 Proceedings of the Petten International Conference, J. R. C. Petten Established $(N-H)$, The Netherlands, March 14-76, 1978, P. 241.

7. Goebel, J. A., Felten, E. J. and Pettit, F. S., "Hot Corrosion Mechanisms for Nickel and Cobalt Base Alloys", Proceedings of the 1974 Gas Turbine Materials in the Marine Environment Conference, MCIC-75-27, Metals and Ceramics Information Center, 1974, p. 93.

8. Hancock, P., "Summation and Examination by Session Chairman of the Various Hypothesis of the Hot Corrosion Mechanism", Proceedings of the 1974 Gas Turbine Materials in the Marine Environment Conference, MCIC75-27, Metals and Ceramics Inforination Center, 1974, p. 225.

9. Shaw, T. R., "The Royal Navy's Service Experience with Gas Turbine Engines", Proceedings of the 1974 Gas Turbine Materials in the Marine Environment Conference, MCIC-75-27, Metals and-Ceramics Information Center, 1974, p. 31.

10. Bessen, I., and Fryxe11, R., "Coating Life Assessment in Gas Turbines Operated for Ship Propulsion", Proceedings of the 1974 Gas Turbine Materials in the Marine Environment Conference, MCIC-75-27, Metals and Ceramics Information Center, 1974, p. 259.

11. Bornstein, N., and DeCrescente, M., "Effects of Vanadium and Sodium Compounds on Accelerated Oxidation of Nickel-Base Alloys", Proceedings of the 1974 Gas Turbine Materials in the Marine Environment Conference, MCIC-75-27, Metals and Ceramics Information Center, 1974, p. 115.

12. Wortman, D. J. et. a1., "Mechanisms of Low Temperature Hot Corrosion: Burner Rig Studies", Thin Solid Films, V. 64, 1979, p. 281. 
13. Bornstein, N. S., DeCrescente, M. A., "The Role of Sodium and Sulfur in the Accelerated Oxidation Phenomena-Sulfidation", Corrosion-NACE, Vol. 26, No. 7, July, 1970, p. 209.

14. Clark, P. V., Fused Salt Mixtures: Eutectic Compositions and Melting Points, SC-R-68-1680 Sandia National Laboratories, ATbuquerque, December 30, 1968 .

15. Daggett Quadrangie, San Bernardino,Co., California, 15 minute series topographic map, U.S. Geological Survey, Denver, Colorado, 1956.

16. Scott, C. A., "Climatology of Daggett California", memo to J. C. Swearengen, SNLL, August 29, 1980.

17. Geologic Map of California, San Bernardino Sheet, California Division of Mines and Geology, Sacramento, California 1967. 
Appendix A

Net Weights for Samples Collected and Analyzed

\begin{tabular}{|c|c|}
\hline Samplc & Weight (mg) \\
\hline ilters & \\
\hline $4-8-80 A$ & bU.I \\
\hline $4-15-80-A$ & 94.6 \\
\hline $4-25-80-A$ & 57.2 \\
\hline $5-2-80-A$ & 92.1 \\
\hline $4-8-80-B$ & 49.6 \\
\hline $4-1680-B$ & $4 \cap .3$ \\
\hline $4-25-80-B$ & 65.5 \\
\hline $5-2-80-B$ & 71.1 \\
\hline $4-8-80-C$ & 46.9 \\
\hline $4-15-80-C$ & 80.6 \\
\hline $4-25-80-C$ & 51.8 \\
\hline $5-2-80-c$ & 63.5 \\
\hline $4-8-80-D$ & 72.0 \\
\hline $4-15-80-D$ & 90.8 \\
\hline $4-25-80-D$ & 14.6 \\
\hline $5-2-80-D$ & 7.4 .8 \\
\hline
\end{tabular}

\section{Tapes}

$\begin{array}{lr}4-8-80-A & 54.7 \\ 4-15-80-\Lambda & 219 . ? \\ 4-8-80-B & 34.6 \\ 4-15-80-B & 98.0 \\ 4-8-80-C & 32.0 \\ 4-15-80-C & 288.5 \\ 4-8-80-D & 49.5 \\ 4-15-80-D & 293.0\end{array}$

Soil

all samples $\quad 1000$ 


\section{Appendix B \\ Procedures for Chemical Analysis}

\section{Prior Preparation}

Tapes were ashed in a furnace at $500^{\circ} \mathrm{C}$ for 2 hours to remove organic material from the tape.

Filters were cut in $1 / 2^{\prime \prime} \times 1 "$ strips to maximize extraction efficiency.

\section{Extraction Methods}

Water: Samples were extracted with $0.02 \mathrm{~m}^{3}$ ASTM Reagent Grade water at $95^{\circ} \mathrm{C}$ for 2 hours. Sample centrifuged and supernatant diluted to $0.04 \mathrm{~m}^{3}$ for $\mathrm{pH}$ and other measurements.

Acid: Centrifuged residues from the water extraction were extracted with $0.02 \mathrm{~m}^{3}$ reagent grade concentrated nitric acid at $86^{\circ} \mathrm{C}$ for 2 hours. Samples centrifuged and supernatant removed for analysis.

Analys is Methods

Metal ions: atomic absorption spectrophotometry. $\mathrm{Cl}^{-}$: colorimetric, $\mathrm{S}^{=}$: titration, $\mathrm{SO}_{4}^{=}$: turbimetric 


\section{Appendix C}

Initial Calibration of High Volume Air Samplers

Sampler

A

R

C

U
Flow Rate $\left(\mathrm{m}^{3} / \mathrm{hr}\right)$

36.5

37.4

24.6

36.5

Volume of Aip Sampled for High Volume Filters Volume $=\frac{\text { Initial Flow Rate }}{2} \times$ hours sampled

Sample

$4-8-80 A$

4-75-80-A

4-25-80-A

$5-2-80-A$

$4-8-80-B$

4-15-80-B

$4-25-80-B$

5-2-80-B

$4-8-80-\bar{C}$

4-15-80-C

4-25-80-C

5-2-80-C

4-8-80-D

4-75-80-D

4-25-80-D

5-2-80-D
Volume of $\operatorname{Air}\left(\mathrm{m}^{3}\right)$

$2.97 \times 10^{3}$

$4.45 \times 10^{3}$

$3.07 \times 10^{3}$

$4.82 \times 10^{3}$

$3.04 \times 10^{3}$

$4.55 \times 10^{3}$

$3.14 \times 10^{3}$

$4.94 \times 10^{3}$

$2.00 \times 10^{3}$

$3.00 \times 10^{3}$

$2.07 \times 10^{3}$

$3.25 \times 10^{3}$

$2.97 \times 10^{3}$

$4.44 \times 10^{3}$

$3.07 \times 10^{3}$

$4.82 \times 10^{3}$

Area of all tape samples: $23800 \mathrm{~mm}^{2}$ 


\section{INITIAL DISTRIBUTION}

U. S. Department of Energy Washington, D.C. 20545

Attn: W. W. Auer

G. W. Braun

M. U. Gutstein

J. E. Rannels

Division of Solar Technology

U.S. Department of Energy

San Francisco Operations Office

1333 Broadway

Oakland, CA 94612

Attn: S. D. Elliott

R. W. Hughey

DOE/STMPO

5301 Bolsa Avenue MS14-1

Huntington Beach, CA. 92647

Attn: R. N. Schweinberg

Aerospace Corporation

P.0. Box 92957

Los Angeles, CA. 90009

Attn: P. Mathur

Babcock \& Wilcox

$20 \mathrm{~S}$. Van Buren Avenue

Barberton, $\mathrm{OH} 44203$

Attn: 0. W. Durrant

G. Grant

Bechtel Corporation

P.0. Box 3965

San Francisco, CA

Attn: E. Lam

Black \& Veatch

P.0. Box 8405

Kansas City, MO 64114

Attn: J. E. Harder

C. L: Mason

Facilities and Services

Marine Corp. LGSP

Barstow, CA 92311

Combustion Engineering, Inc. 1000 Prospect Hill Road

Windsor, Connecticut 06095

Attn: H. M. Payne
Energy Systems and Technology Dịyịsịon General Electric Co. 310 DeGuigne Drive Sunnyvale, CA 94086

Attn: Sig Wolf

ETEC/STMPO

P.0. Box 1449

Canoga Park, CA 91304

Attn: K. L. Adler

Energy Systems Group

Rockwel'l International

P.0. Box 1449

8900 DeSoto Avenue

Canoga Park, CA 91304

Attn: T. Johnsen

Foster Wheeler Energy Corporation

110 South Orange Avenue

Livingston, New Jersey 0.7039

Attn: R. J. Zoschak

Los Angeles Department of Water \& Power P.0. Box 111

Los Angeles, CA 90051

Attn: H. D. Bradley

Martin Marietta Corporation

P.0. Box 179

Denver, CO 80201

Attn: T. R. Tracey

McDonnell Douglas

5301 Bolsa Avenue

Huntington Beach, CA 92647

Attn: G. Colemain

R. Gervais

R. Easton

Rocketdyne Division

Rockwel] International Corporation

6633 Canoga Avenue

Canoga Park, CA 91304

Attn: J. M. Friefeld

Southern California Edison

P.0. Box 800

Rosemead, CA 91770

Attn: J. Reeves

C. Winarski 
Stearns-Roger

P.0. Box 5888

Denver, CO 80217

Attn: W. R. Lang

J. H. Scott, 4700

G. E. Brandvold, 4710

J. Otts, 4713

T. B. Cook, 8000; Attn:

D. M. 01son, 8100

A. N. Blackwell, 8200

L. Gutierrez, 8400

W. E. Alzheimer, 8120 .

C. S. Hoyle, 8122

L. Napolitano, 8122

M. Abrams, .8124

R. J. Gallagher, 8I'24

B. F. Murphey, 8300

D. M. Schuster, 8310

R. W. Mar, 8313

A. J. West, 8314

L. A. Wert, 8315

J. C. Swearengen, 8316

D. A. Hughes, 8316 (10)

C. S. Selvage, 8450

C. T. Yokomizo, 8451

A. C. Skinrood, 8452

E. T. Cull, 8452

W. G. Wilson, 8453

Publications Division, 8265, for TIC (27)

Publications Division, 8265/Technical Library Processes and Systems Division, 3141 Techntcal Library Processes Division, 3141 (3)

M. A. Pound, 8214, for Central Technical Files (3) 


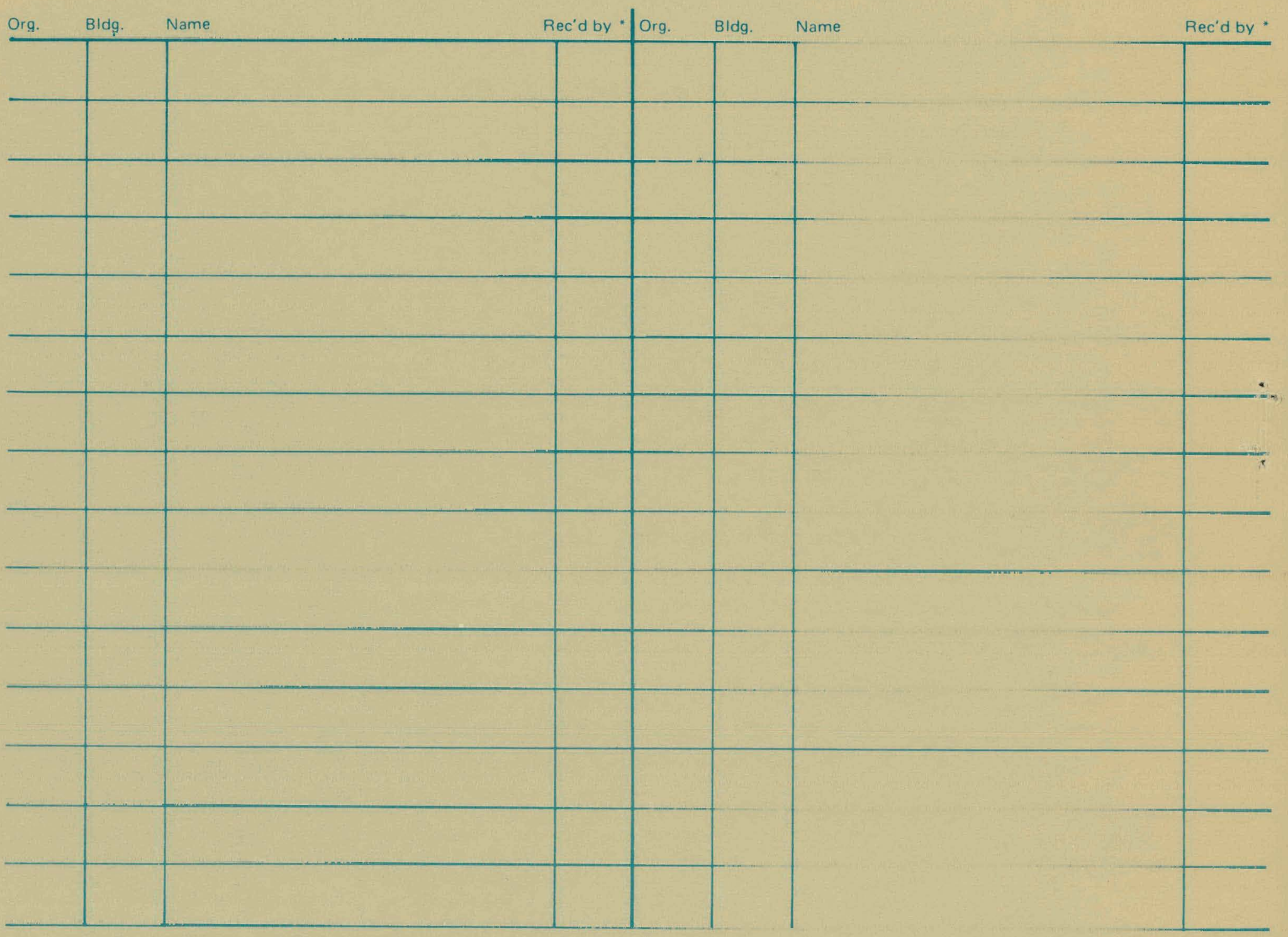

